Prof. Dr. Robert Uerpmann-Wittzack, Universität Regensburg

www.ur.de/law/public-law/uerpmann-wittzack/

robert.uerpmann-wittzack@ur.de

\title{
Immunities before International Criminal Courts
}

\section{Introduction}

Under a well-established rule of international law, heads of State enjoy complete personal immunity before the domestic jurisdictions of other States during their term of office. ${ }^{1}$ This immunity has been confirmed by the International Court of Justice (ICJ) in the Arrest Warrant Case in $2002 .^{2}$ The Court determined that this immunity covered not only heads of State and government but also ministers for foreign affairs, and it stressed the functional nature of these immunities. Dealing specifically with ministers for foreign affairs, the court stated that immunities were accorded in order 'to ensure the effective performance of their functions on behalf of their respective States'. ${ }^{3}$ Ministers for foreign affairs have full powers to represent their States. Being responsible for the relations of their States with other States, they are frequently obliged to travel. If they were arrested in another State, this would hinder them from exercising the functions of their office. ${ }^{4}$ This explains why their immunity must be absolute, covering also acts committed in a private capacity ${ }^{5}$ and even most serious crimes. ${ }^{6}$ The Court added, however, that immunities do not bar prosecution by 'certain international courts' such as the International Criminal Tribunal for the former Yugoslavia (ICTY) and the International Criminal Court (ICC). ${ }^{7}$

In fact, the Statutes of these courts exclude any immunity to be applied to heads of State, Ministers for foreign affairs or other officials. According to Article 7(2) of the ICTY Statute ' $[\mathrm{t}]$ he official position of any accused person, whether as head of State or Government or as a

\footnotetext{
${ }^{1}$ See H Fox and P Webb, The Law of State Immunity (Oxford, Oxford University Press, 2013) 544 et seq.; J Klabbers, International Law (Cambridge, Cambridge University Press, 2013), 102; see also A Cassese, International Law (Oxford, Oxford University Press, 2005), 117-118.

${ }^{2}$ ICJ, Arrest Warrant of 11 April 2000 (Democratic Republic of the Congo v. Belgium), Judgment, ICJ Reports 2002, p. 3.

${ }^{3}$ Ibid, para 53 .

${ }^{4}$ Ibid, para 55.

${ }^{5} \mathrm{Ibid}$, para 55.

${ }^{6} \mathrm{Ibid}$, para 58.

${ }^{7}$ Ibid, para 61 .
} 
responsible Government official, shall not relieve such person of criminal responsibility nor mitigate punishment.' Article 27(2) of the Rome Statute of the International Criminal Court is even more explicit: 'Immunities or special procedural rules which may attach to the official capacity of a person, whether under national or international law, shall not bar the Court from exercising its jurisdiction over such a person.' By acceding to the Rome Statute, a State accepts Article 27(2) of the Statute and thereby foregoes immunities of its head of State and other representatives. However, some questions remain with regard to the representatives of third States that are not parties to the Rome Statute, and even with regard to State parties representatives Article 27(2) of the Rome Statute has been challenged recently.

In order to give a factual background, Section II will review the cases of Slobodan Milošević, Omar Al Bashir, Muammar Gaddafi and Uhuru Kenyatta. While the presidents of the former Yugoslavia, Sudan and Libya where prosecuted without the consent of their respective States, these proceedings were widely accepted by the international community. The Kenyan Kenyatta case, however, provoked strong reactions within Africa although it concerns a State party to the Rome Statute. With a special view to the Al Bashir and Gaddafi cases, Section III will address third party effects under the Rome Statute. Section IV takes a more basic approach. Drawing on Max Weber's distinction between the 'ethic of principled conviction' (Gesinnungsethik) on the one hand and the 'ethic of responsibility' (Verantwortungsethik) on the other hand, ${ }^{8}$ this section seeks to elucidate the ratio of granting immunities to incumbent heads of State. Finally, Section V asks whether ex officio criminal prosecution should be complemented by a political element.

\section{Cases}

\section{A Slobodan Milošević}

On 22 May 1999, the International Criminal Tribunal for the former Yugoslavia (ICTY) indicted the Serbian President Slobodan Milošević while he was still in office. ${ }^{9}$ This was in conformity with Article 7(2) of the ICTY Statute, which explicitly allows the Tribunal to

\footnotetext{
${ }^{8}$ See M Weber, Politik als Beruf (Duncker und Humblot, München, 1919), 56 et seq.; English translation: M Weber, 'The Profession and Vocation of Politics', in M Weber, Political Writings, ed by P Lassman and R Speirs (Cambridge, Cambridge University Press, 1994), 309, 359 et seq.; see also R Uerpmann-Wittzack, 'Serious Human Rights Violations as Potential Exceptions to Immunity: Conceptual Challenges', in A Peters, E Lagrange, S Oeter and C Tomuschat (eds), Immunities in the Age of Global Constitutionalism (Leiden, Brill, 2014), 236, 240.

${ }^{9}$ ICTY, The Prosecutor of the Tribunal against Slobodan Milošević et al, Indictment of 22 May 1999, Case No. IT-99-37, para 55 (retrievable at http://www.icty.org/case/slobodan_milosevic/; all internet documents last checked on 26.4.2016).
} 
prosecute heads of State. So any immunity of incumbent heads of State is discarded. The ICTY Statute was enacted by the UN Security Council acting under Chapter VII of the UNCharter. ${ }^{10}$ So, the decision to deny immunities is based on Security Council powers under Chapter VII. ${ }^{11}$

\section{B Omar Al Bashir and Muammar Gaddafi}

On 4 March 2009, the International Criminal Court (ICC) issued an arrest warrant against the still serving Sudanese President Omar Al Bashir. This is interesting because Sudan is not a member of the Rome Statute and it has not recognised the competences of the ICC. However, the proceedings against Al Bashir were triggered by the Security Council. On 31 March 2005, the Security Council determined that the Darfur crisis continued to constitute a threat for international peace and security and, acting under Chapter VII UN Charter, it referred the situation in Darfur to the ICC. ${ }^{12}$ The referral empowers the ICC to prosecute crimes under Article 13 lit. b Rome Statute even though Sudan is not a State party of the Statute. As the Security Council acted under Chapter VII UN Charter, it had the power to discard the immunity of a non-State-party head of State. It is true that Security Council Resolution 1593 (2005), which referred the situation in Darfur to the ICC, did not explicitly waive immunities. However, when availing itself of the option offered by Article 13 lit. b Rome Statute, the Security Council implicitly adopts all relevant rules of the Rome Statute including its Article 27 on immunities, unless the Council explicitly decides otherwise. ${ }^{13}$

On 14 October 2011, President Al Bashir visited Malawi in order to attend a summit of the Common Market for Eastern and Southern Africa (COMESA). ${ }^{14}$ Unlike Sudan, Malawi is a State party to the Rome Statute. So, in principle, Malawi would have been obliged to execute the arrest warrant against President Al Bashir under Article 89(1) Rome Statute. However, no action was taken against President Al Bashir when he visited Malawi in October 2011. According to Malawi, Article 27(2) of the Statute was not applicable to Al Bashir because

\footnotetext{
${ }^{10}$ See S/RES/827(1993); last Amendment S/RES/1877(2009).

${ }^{11}$ R Uerpmann-Wittzack 'Immunität vor Internationalen Strafgerichten', (2006) 44 Archiv des Völkerrechts 33, 37-38

${ }^{12} \mathrm{~S} / \mathrm{RES} / 1593(2005)$.

${ }^{13}$ D Akande, 'The Legal Nature of Security Council Referrals to the ICC and its Impact on Al Bashir's Immunities' (2009) 7 Journal of International Criminal Justice 333, 340-341; Uerpmann-Wittzack, supra, note 11, 41-42; see also C Kreß, 'The International Criminal Court and Immunities under International Law for States Not Party to the Court's Statute', in M Bergsmo and Y Ling (eds), State Sovereignty and International Criminal Law (Beijing, Torkel Opsahl Academic EPublisher, 2012), 223, 241.

${ }^{14}$ ICC, Pre-Trial Chamber I, decision of 12 December 2011, ICC-02/05-01/09-139, paras 5, 8.
} 
Sudan was not a member to the Statute. ${ }^{15}$ Malawi could also have relied on Art. 98(1) of the Rome Statute under which the Court must not bring the requested State in a situation where it would have 'to act inconsistently with its obligations under international law with respect to the State or diplomatic immunity of a person or property of a third State, unless the Court can first obtain the cooperation of that third State for the waiver of the immunity.' In a decision of 12 December 2011, however, a pre-trial chamber of the ICC rejected both arguments. The chamber asserted a general rule of international law under which immunity of heads of States may not be invoked before international courts. ${ }^{16}$ This immunity exception, which would cover all proceedings before all international criminal courts, might be too broad. In the case at hand, there was no need to settle the question of immunities before international courts in general. As the chamber rightly added, the proceedings against Al Bashir were started following a referral by the Security Council acting under Chapter VII of the UN Charter. ${ }^{17}$ So, the Al Bashir case before the ICC is similar to the Milošević case ${ }^{18}$ before the ICTY: In both cases, the immunity exception finds its basis in Chapter VII of the UN Charter.

The Gaddafi case also enters into this line. On 26 February 2011, the Security Council referred the situation in Libya to the ICC,${ }^{19}$ thus authorising the prosecution of the then incumbent head of State.

\section{Uhuru Kenyatta}

On 31 March 2010, ICC Pre-Trial Chamber II authorised an investigation under Article 15(4) Rome Statute with regard to crimes committed in Kenya before and after the Presidential elections of 2007, i.e. between 2005 and 2009. ${ }^{20}$ Eventually, the winner of the 2007 election, incumbent Kenyan President Uhuru Kenyatta, was indicted and Pre-Trial Chamber II confirmed charges against him on 23 January 2012. ${ }^{21}$ The denial of head of State immunity is in line with Article 27 Rome Statute. ${ }^{22}$ As Kenya is a party to the Rome Statute, it has accepted the immunity exception. Thus, prosecuting the incumbent head of State seems

\footnotetext{
${ }^{15}$ Ibid, para 8.

${ }^{16}$ Ibid, para 36.

${ }^{17} \mathrm{Ibid}$; see also Akande, supra, note 13, 340-342, with regard to the effects of the Security Council resolution.

${ }^{18}$ See, supra, at II A.

${ }^{19} \mathrm{~S} / \mathrm{RES} / 1970(2011)$, para 4.

${ }^{20}$ Situation in the Republic of Kenya, Authorisation of 31 March 2010, ICC-01/09-19, p. 83.

${ }^{21}$ ICC-01/09-02/11-382, p. 154.

${ }^{22}$ This has been confirmed in an obiter dictum by Trial Chamber V(B), Decision of 18 October 2013, ICC01/09-02/11-830, para 120.
} 
hardly problematic from a legal point of view. Nevertheless, the Kenyatta indictment met strong opposition not only within Kenya but also among other African States.

On 23 October 2013, the Assembly of the African Union adopted a Decision on Africa's Relationship with the International Criminal Court that was specifically motivated by the Kenyatta proceedings. ${ }^{23}$ According to the Assembly, the indictment of the sitting head of State Kenyatta 'could undermine the sovereignty, stability, and peace in that country and in other Member States' $;{ }^{24}$ criminal proceedings before the ICC would 'distract and prevent' the head of State 'from fulfilling ... [his] constitutional responsibilities, including national and regional security affairs'. ${ }^{25}$ Therefore, no 'serving AU head of State or Government' should be prosecuted by any International Criminal Court or Tribunal during their terms of office in order 'to safeguard the constitutional order, stability and, integrity of Member States' ${ }^{26}$ This strong commitment to head of State immunity is astonishing since 34 African States are parties to the Rome Statute ${ }^{27}$ thus having renounced at head of State immunity under Article 27(2) of the Statute.

At the initiative of the African Union, the ICC Assembly of States Parties organised a panel discussion on the 'Indictment of sitting heads of State and Government and its consequences on peace and stability and reconciliation' on 21 November $2013 .{ }^{28}$ Whilst amending Article 27(2) Rome Statute seemed unrealistic, ${ }^{29}$ appropriate amendments to the Rules of Procedure and Evidence were envisaged. ${ }^{30}$ In fact, such amendments were adopted on 27 November $2013 .^{31}$ In particular, Rule 134quater now provides that an accused person 'who is mandated to fulfil extraordinary public duties at the highest national level' may be excused from presence during the trial.

Meanwhile, the proceedings against President Kenyatta are about to fail. As the Kenyan Government obviously did not co-operate, the Prosecutor saw no possibility to provide the

\footnotetext{
${ }^{23}$ AU Doc. Ext/Assembly/AU/Dec.1(Oct.2013).

${ }^{24}$ Ibid para 5.

${ }^{25}$ Ibid para 6.

${ }^{26}$ Ibid para 10 (i).

${ }^{27}$ See the information provided by the ICC at: http://www.icccpi.int/en_menus/asp/states\%20parties/african\%20states/Pages/african\%20states.aspx.

${ }^{28}$ ICC-ASP/12/61 of 27 November 2013, para 5.

${ }^{29}$ Ibid, para 8 .

${ }^{30}$ Ibid.

${ }^{31}$ Resolution ICC-ASP/12/Res.7.
} 
necessary evidence for a condemnation. On 3 December 2014, Trial Chamber V(B) refused an application to further adjourn the proceedings ${ }^{32}$ and, as a consequence, the Prosecutor withdrew the charges on 5 December $2014 .^{33}$

\section{The Rome Statute and Third Parties}

When dealing with third party effects, three types of cases must be distinguished. The first category is constituted by cases where proceedings are opened against heads of States, which are members to the Rome Statute. The Kenyatta case falls in this category. By ratifying the Rome Statute, Kenya has accepted Article 27(2) of the Statute thereby waving any immunity otherwise accorded to its head of State. Prosecution is possible, and there is no third party effect.

Cases, where prosecution has been authorised by the Security Council acting under Chapter VII of the UN Charter, form the second category. The cases of Milošević, Al Bashir and Gaddafi are examples of this important category. Prosecution is legitimised by Chapter VII powers which prevail even over the customary immunity of heads of State. It is true that the resolutions referring the situations in Darfur and in Libya to the ICC do not explicitly exclude immunities. By referring a case to the ICC, however, the Security Council makes use of the option foreseen in Article 13 lit. b Rome Statute. Thereby, it implicitly confirms all relevant provisions of the Rome Statute including its Article 27(2). Under Chapter VII of the UN Charter, the Security Council has the discretionary power to restrict prosecution to certain persons or to exclude certain persons from prosecution. So, the Security Council would be entitled to exempt incumbent heads of State from prosecution. In the cases at hand, however, the Security Council did not use this option. Quite to the contrary, the Sudan resolution expressly refers to nationals and officials of States not member to the Rome State other than Sudan, who operate in Sudan on the basis of a Security Council or an African Union resolution, and exempts these persons from prosecution. ${ }^{34} \mathrm{~A}$ similar provision is contained in the resolution on Libya. ${ }^{35}$ Under these circumstances the silence with regard to immunities of the incumbent heads of State of Sudan and Libya indicate that the ICC fully endorsed Article 27(2) of the Rome Statute with regard to the Sudanese President Al Bashir and to the Libyian leader Gaddafi.

\footnotetext{
${ }^{32}$ ICC-01/09-02/11-981, p. 26.

${ }^{33}$ ICC-01/09-02/11-983.

${ }^{34}$ S/RES/1593(2005), para 6.

${ }^{35} \mathrm{~S} / \mathrm{RES} / 1970(2011)$, para 6.
} 
The third category comprises proceedings against heads of State of non-ICC-Member States where the situation has not been referred to the ICC by the Security Council. This has not yet happened before the ICC. Under the traditional law of treaties, as laid down in Article 34 of the 1969 Vienna Convention on the Law of Treaties, Article 27(2) Rome Statute cannot be applied to a head of State of a non-member State without that State's consent. ${ }^{36}$ It is true that a customary rule, which would give Article 27(2) Rome Statute erga omnes effect, is increasingly asserted. ${ }^{37}$ So far, however, there is little practice pointing into this direction. Two cases merit attention.

In 2003, the Special Court for Sierra Leone issued an arrest warrant against then incumbent President of Liberia Charles Taylor. ${ }^{38}$ This was even more problematic than an arrest warrant issued by the ICC since the Special Court for Sierra Leone was only a so-called semiinternational or hybrid tribunal, and it was not completely independent from the State of Sierra Leone. ${ }^{39}$ Moreover, the trial only took place when Charles Taylor was not in office any more, and the State of Liberia then consented to the proceedings against its former head of State. ${ }^{40}$ Under these circumstances, the Taylor case gives little evidence as to the permissibility of criminal proceedings against incumbent heads of State before international courts.

In the Al Bashir case, the Pre-Trial Chamber justified proceedings against an incumbent head of State in a way which would apply to heads of State of member and of non-member States alike. $^{41}$ The fact that the situation in Darfur had been referred by the Security Council only constituted an additional argument for the Chamber. ${ }^{42}$ It must be kept in mind, however, that the ICC has never started proceedings against non-member State heads of State without Security Council consent. This limits the argumentative weight of the broader approach taken

\footnotetext{
${ }^{36}$ See also D Akande, 'International Law Immunities and the International Criminal Court' (2004) 98 American Journal of International Law, 407, 433.

${ }^{37}$ See e.g. the careful analysis given by Kress, supra, note 13, 250-256, 262-263; see also M Frulli, 'Piercing the Veil of Head-of-State Immunity: The Taylor Trial and Beyond' in CC Jalloh (ed), The Sierra Leone Special Court and its Legacy (Cambridge, Cambridge University Press, 2013) 325, 333: 'emerging trend'.

${ }^{38}$ Special Court for Sierra Leone, The Prosecutor against Charles Ghankay Taylor, Warrant of Arrest and Order for Transfer and Detention, 7 March 2003, SCSL 2003-01-I-004 (available through http://www.rscsl.org/Taylor_Trial_Chamber_Decisions.html).

${ }^{39}$ For the status of the Special Court see A Cassese, P Gaeta et al., Cassese's International Criminal Law (Oxford, Oxford University Press, 2013), 263-267.

${ }^{40}$ See Frulli, supra, note 37, pp. 336, 338, with regard to Taylor's arrest.

${ }^{41}$ See, supra, note 16.

${ }^{42}$ See, supra, note 17.
} 
by the Pre-Trial Chamber when explaining why President Al Bashir could not avail himself of immunity.

Both the Special Court for Sierra Leone ${ }^{43}$ and the ICC Pre-Trial Chamber ${ }^{44}$ relied on the ICJ statement made in the Arrest Warrant case ${ }^{45}$ that immunities did not apply before 'certain international courts' such as the ICC. However, this short obiter dictum must not be over interpreted. The ICJ statement is definitely correct when proceedings are started against heads of ICC Member States like President Kenyatta or where a situation has been referred to the ICC by Security Council resolution like in the Al Bashir case. In the Arrest Warrant case, the ICJ did not have to decide whether the same would be true in other cases.

Finally, the Security Council resolutions 1593 (2005) on Sudan and 1970 (2011) on Libya, which protect certain non-member State nationals from prosecution, ${ }^{46}$ show that the Council does not take an erga onmes effect as granted. Summing up, a rule giving Article 27(2) of the Rome Statute erga onmes effect cannot to date be established under customary international law, although such a rule might eventually emerge.

\section{Ethic of Principled Conviction vs. Ethic of Responsibility}

Although it is clear that incumbent Kenyan President Kenyatta may not avail himself of immunities before the ICC under existing international law, the ICC decision to open proceedings against him was highly controversial, provoking strong reactions by the African Union. ${ }^{47}$ This shows at least a certain uneasiness with Article 27(2) Rome Statute as it actually stands. Recourse to ethical standards may help explaining this uneasiness. Following World War I, the German scholar Max Weber published his small treatise on the Vocation and Profession of Politics (Politik als Beruf) in 1919. ${ }^{48}$ Weber distinguished two different kinds of ethics: The 'ethic of principled conviction' or 'ethic of absolute ends ${ }^{, 49}$ (Gesinnungsethik) on the one hand, and the 'ethic of responsibility' (Verantwortungsethik) on

\footnotetext{
${ }^{43}$ Special Court for Sierra Leone, Appeals Chamber, The Prosecutor against Charles Ghankay Taylor, Decision on Immunity from Jurisdiction, 31 May 2004, SCSL 2003-01-I-059, paras 50-52 (available through http://www.rscsl.org/Taylor_Appeals_Chamber_Decisions.html).

${ }^{44}$ ICC, Pre-Trial Chamber I, see, supra, note 14, paras 33-36.

${ }^{45}$ See, supra, note 7.

${ }^{46}$ See, supra, notes 34-35.

${ }^{47}$ See, supra, at II C.

${ }^{48}$ See, supra, note 8.

${ }^{49}$ See the translation provided by H H Gerth and C Wright Mills (eds), 'Politics as a Vocation', in M Weber, Essays in Sociology (London, Lowe and Brydone, 1967), 77, 122, 126, 127; see also ibid, 120-122, 124, 127: 'responsibility of ultimate ends'.
} 
the other hand. Under the ethic of principled conviction or absolute ends, criminal justice must be done regardless of the consequences which prosecution may have for international relations. Under the ethic of responsibility, by contrast, these consequences must be considered, and immunities may be useful in order to prevent prosecution which would harm international relations.

In the Al Bashir case, the Pre-Trial Chamber had to deal with immunities when it decided on Malawi's refusal to co-operate with the ICC. The Chamber relied on Antonio Cassese ${ }^{50}$ in order to explain why no immunities applied before international criminal courts. ${ }^{51}$ According to the Chamber, immunities applied before foreign domestic courts because abusive prosecution might have negative effects on international relations. As international courts like the ICC were totally independent of States and strictly impartial, however, the Chamber excluded any abusive prosecution by international criminal courts. Therefore, it saw no reason to grant immunities before these courts. While arguing so, the Chamber did not consider that even well-founded prosecution may hinder a head of State from acting internationally and may thus impede international relations. These consequences have also been invoked by the African Union in its 2013 Decision on Africa's Relationship with the ICC. ${ }^{52}$ The ICC Chamber ignores them.

It is striking to see that the ICJ adopted a different approach in the Arrest Warrant case. In order to show that Ministers for Foreign Affairs enjoyed the same immunities as heads of State and Government, the ICJ took a functional approach. As seen above, ${ }^{53}$ the ICJ demonstrated that incumbent ministers for foreign affairs needed personnel immunity in order to fulfil their functions. Even though the ICJ confirmed in the same judgment that immunities did not apply before 'certain international courts', ${ }^{54}$ the functional approach hints into another direction: If immunities for heads of State and Government and for ministers for foreign affairs are necessary in order to enable States to communicate with other States, there are good reasons to apply these immunities even before international courts. This reasoning confirms that heads of non-ICC-Member St ates should be granted immunity unless the

\footnotetext{
${ }^{50}$ A Cassese, International Criminal Law (Oxford, Oxford University Press, 2008), 312; now Cassese, Gaeta et al., see, supra, note 39, 321.

${ }^{51}$ Pre-Trial Chamber I, note 14, para 34; see also Frulli, supra, note 37, at 330; Kreß, supra, note 13, 250.

${ }^{52}$ See, supra, text accompanying note 25.

${ }^{53}$ See, supra, notes 3-4.

${ }^{54}$ See, supra, note 7.
} 
Security Council has referred a situation to the ICC. ${ }^{55}$ At the same time, one may question whether the automatism in prosecuting incumbent heads of ICC member States like President Kenyatta is really appropriate.

In fact, international prosecution of an incumbent head of State does not seem problematic, when there is an international consensus not to co-operate with this head of State any more. Such a consensus may be presumed when the Security Council adopts a resolution under Chapter VII of the UN Charter referring a situation to the ICC or to another international criminal court. Thus, the arrest warrants against Serbian President Milošević and Libyan leader Gaddafi did not endanger international relations. In the Al Bashir this is already less evident, as Malawi's refusal to co-operate with the ICC shows. In the Kenyatta case, by contrast, international consensus not to co-operate with the Kenyan regime is obviously missing. This explains the determined reaction by the African Union.

\section{Criminal Prosecution and Political Control}

The last section shall analyse whether prosecution of incumbent heads of States can be limited to cases where there is an international consensus among States not to co-operate with these heads of State any more.

A first means is provided by Article 13 lit. b of the Rome Statute. When deciding to refer a situation to the ICC, the Security Council should examine whether criminal prosecution is appropriate even though it may impede international co-operation. Moreover, Article 16 Rome Statute enables the Security Council to defer proceedings under Chapter VII UN Charter, i.e. in situations where international peace and security is threatened. The African Union urged the Security Council to do so in the Kenyatta case ${ }^{56}$ but without success. In fact, draft resolution S/2013/660, which was introduced by Kenya and thirteen other, mostly African States only received seven affirmative votes ${ }^{57}$ and missed the required majority of nine votes under Article 27(3) UN Charter.

One might argue that the true problem of the Kenyatta case was not a procedural one but an expansive reading of substantial international criminal law and a lack of evidence. In fact,

\footnotetext{
${ }^{55}$ See, supra, at II.

${ }^{56}$ Decision on Africa's Relationship with the International Criminal Court (ICC), see, supra, note 23, para 10 iii and ix; see also the letter from the Permanent Representative of Kenya to the United Nations of 22 October 2013 with annexes, UN Doc. S/2013/624.

${ }^{57}$ See Security Council, $7060^{\text {th }}$ meeting, 15 November 2013, UN Doc. S/PV.7060, p. 2.
} 
Judge Kaul severely criticised the very beginning of an investigation. In his dissenting opinion to the authorisation of investigations of 31 March 2010, ${ }^{58}$ Judge Kaul agreed that there was 'chaos, anarchy, a collapse of State authority in most parts of the country and almost total failure of law enforcement agencies, ${ }^{59}$ but he felt unable to see a State policy which would turn this chaos into a consistent attack on the civilian population within the meaning of Article 7(1) Rome Statute. ${ }^{60}$ In fact, it is certainly wise to use the instrument of international criminal justice with utmost care and to trigger international prosecution only in the most serious cases where clear evidence is available. ${ }^{61}$ Greater prudence and reserve could have avoided the turmoil around the Kenyatta proceedings.

The underlying problems might be more fundamental, though. In fact, international criminal law is trapped between the structural needs of public international law on the one hand and criminal law on the other hand. Public international law as it stands is the expression of an international order that is still built in essence on sovereign States. In this situation, international law must give leeway to diplomacy, inter-state negotiations and political solutions. Immunities serve this purpose. They shall not only prevent abusive criminal prosecution. Even non-abusive prosecution by international criminal courts may seriously impede international relations, as the Kenyan example shows, and this is where the Pre-Trial Chamber in Al Bashir erred. ${ }^{62}$ Thus, granting immunities is perfectly in line with the pragmatic approach of general international law, which is characterised by Max Weber's ethic of responsibility (Verantwortungsethik). From a criminal law perspective, however, justice must be done regardless of political considerations. International criminal law must be based on the ethic of principled conviction (Gesinnungsethik). Subordinating the prosecution of senior officials to a decision of political opportunity, would compromise the very idea of a general international criminal court. ${ }^{63}$ It seems impossible to solve this fundamental conflict as long as independent States continue to be the key actors of the international order.

\footnotetext{
${ }^{58}$ Situation in the Republic of Kenya, Authorisation of 31 March 2010, ICC-01/09-19, Dissenting Opinion Judge Kaul.

${ }^{59}$ Ibid, para 153 .

${ }^{60} \mathrm{Ibid}$, paras $148-152$.

${ }^{61}$ See also Kreß, supra, note 13, 265.

${ }^{62}$ See, supra, text accompanying note 51.

${ }^{63}$ See also Kreß, supra, note 13, 248-249.
} 